\title{
PENGEMBANGAN MODUL MATEMATIKA BERBASIS DISCOVERY LEARNING BERBANTUAN FLIPBOOK MAKER UNTUK MENINGKATKAN KEMAMPUAN PEMAHAMAN KONSEP PADA MATERI SEGITIGA
}

\author{
Fhina Haryanti ${ }^{1}$, Bagus Ardi Saputro ${ }^{2}$ \\ Universitas PGRI Semarang \\ $\mathbf{1}_{\text {fhina_jeparaz@yahoo.co.id }}$ \\ ${ }^{2}$ bagusardisaputro@yahoo.co.id
}

\begin{abstract}
ABSTRAK
Penelitian bertujuan untuk mengembangkan bahan ajar berupa modul matematika berbasis discovery learning berbantuan flipbook maker yang valid untuk meningkatkan kemampuan pemahaman konsep siswa pada materi segitiga dan menghasilkan modul matematika berbasis discovery learning berbantuan flipbook maker yang efektif untuk meningkatkan kemampuan pemahaman konsep siswa pada materi segitiga. Metodologi penelitian yang digunakan adalah R\&D model ADDIE dengan tahap Analysis (Analisis), Desain (Perancangan), Development (Pengembangan), Implementation (Implementasi) dan Evaluation (Evaluasi). Pada penelitian eksperimen populasi dalam penelitian ini adalah kelas VII SMP Negeri 1 Mlonggo yang terdiri dari delapan kelas. Dengan teknik "Cluster Random Sampling" didapatkan Kelas VII D sebagai kelas eksperimen dan kelas VII E sebagai kelas kontrol. Hasil validasi ahli rata-rata kelayakan materi sangat baik yaitu $82,03 \%$ dan validasi ahli media sangat baik yaitu $81,25 \%$. Angket tanggapan siswa $83,92 \%$ yang berkriteria sangat baik. Jadi bahan ajar yang dikembangkan valid untuk diimplementasikan. Hasil penelitian menunjukkan $t_{\text {hitung }}>t_{\text {tabel }}$ yaitu $3.050>1.67$ maka hipotesis $\mathrm{H}_{0}$ ditolak, jadi rata-rata hasil belajar siswa yang menggunakan modul matematika berbasis Discovery Learning berbantuan Flipbook Maker pada materi segitiga lebih baik daripada rata-rata hasil belajar siswa yang tidak menggunakan modul matematika berbasis Discovery Learning berbantuan Flipbook Maker pada materi segitiga. Sehingga modul tersebut efektif untuk meningkatkan kemampuan pemahaman konsep siswa pada materi segitiga.
\end{abstract}

Kata Kunci : Discovery Learning, Flipbook Maker, Kemampuan Pemahaman Konsep, Segitiga.

\section{PENDAHULUAN}

Matematika merupakan suatu mata pelajaran yang diajarkan pada setiap jenjang pendidikan di Indonesia mulai dari Sekolah Dasar (SD) sampai Sekolah Menengah Atas (SMA). Tujuan pelajaran matematika bertujuan agar siswa memiliki kemampuan berikut ini, (1) Memahami konsep matematika, menjelaskan keterkaitan antar konsep dan mengaplikasikan konsep atau algoritma secara luwes, akurat, efisien, dan tepat dalam pemecahan masalah, (2) Menggunakan penalaran pada pola dan sifat, melakukan manipulasi matematika dalam membuat generalisasi, menyusun bukti, atau menjelaskan gagasan dan pernyataan matematika, (3) Memecahkan masalah yang meliputi kemampuan 
memahami masalah, merancang model matematika, menyelesaikan model, dan menafsirkan solusi yang diperoleh, (4) Mengkomunikasikan gagasan dengan simbol, tabel, diagram atau media lain untuk memperjelas keadaan atau masalah, (5) Memiliki sikap menghargai kegunaan matematika dalam kehidupan, yaitu memiliki rasa ingin tahu, perhatian, dan minat dalam mempelajari matematika serta sikap ulet dan percaya diri dalam pemecahan masalah (Wardhani, S. 2008).

Zulkardi (dalam Herawati, O. D. P., Siroj, Rusdy dan Basir H. M. D. 2010: 71) mengatakan bahwa mata pelajaran matematika itu menekankan pada konsep, artinya dalam mempelajari matematika siswa harus memahami konsep matematika terlebih dahulu agar dapat menyelesaikan soal-soal dan mengaplikasikan masalah-masalah dalam dunia nyata. Padahal menurut Yenni \& Komalasari (2016) kemampuan pemahaman matematis siswa tingkat SMP masih rendah. Sehingga pemahaman konsep siswa terhadap materi matematika perlu mendapat perhatian khusus untuk dikembangkan.

Sedangkan pada umumnya bahan ajar yang ada sekarang ini sifatnya monoton dan langsung menyajikan materi sehingga membuat siswa bosan dan tidak ada aktifitas siswa dalam belajar. Bahan ajar haruslah memiliki bentuk, isi dan cara penyajian materi yang unik dan menarik supaya dapat menarik minat siswa untuk belajar menggunakan bahan ajar tersebut. Salah satu bahan ajar yang menarik untuk dikembangkan adalah modul. Russel (dalam Wena, M.2013:224) mengemukakan bahwa sistem pembelajaran modul akan menjadikan pembelajaran lebih efesien, efektif dan relevan.

Dalam upaya meningkatkan kemampuan pemahaman konsep, guru perlu mempersiapkan dan mengatur strategi penyampaian materi matematika kepada siswa. Strategi tersebut dapat berupa memilih bahan ajar yang dipadukan dengan model pembelajaran yang tepat dimana siswa dilibatkan secara aktif dalam proses pembelajaran sehingga dapat meningkatkan kemampuan pemahaman konsep pada siswa dan tercapainya hasil belajar siswa yang diharapkan. Peran guru dalam kegiatan belajar mengajar adalah sebagai fasilitator dan motivator untuk mengoptimalkan belajar siswa. Guru seharusnya tidak memberi pengetahuan jadi, tetapi hendaknya secara aktif membangun pengetahuan dalam pikiran mereka sendiri. Oleh karena itu diperlukan pendekatan pembelajaran yang dapat mengaktifkan siswa dalam kegiatan belajar mengajar (Misdalina, Zulkardi dan Purwoko: 2009).

Guru harus memilih model pembelajaran yang sesuai dengan tujuan dan materi pembelajaran. Model pembelajaran yang dipilih haruslah model pembelajaran yang 
mampu meningkatkan peran siswa dalam proses pembelajaran. Model pembelajaran tersebut diantaranya adalah discovery learning. Model pembelajaran discovery learning merupakan suatu cara untuk mengembangkan belajar siswa aktif dengan menemukan sendiri dan menyelidiki sendiri sehingga siswa dapat menemukan sendiri suatu konsep dari pembelajaran. Menurut Dahar, R. W. (1996:81) Pembentukan konsep merupakan suatu bentuk belajar penemuan (discovery learning). Jadi model discovery learning baik digunakan untuk meningkatkan kemampuan pemahaman konsep.

Selain penggunaan model pembelajaran, keberadaan media juga dapat berpengaruh terhadap peningkatan pemahaman konsep matematika. Menurut Henick dkk, (dalam Suherman, E., dkk. 2003:237) pada bukunya, Intructional Media and Technologi for Learning, menyatakan bahwa keseluruhan sejarah, media dan teknlogi telah mempengarui pendidikan. Dalam hal ini media yang akan digunakan adalah flipbook maker, Flipbook maker adalah sebuah software yang mempunyai fungsi untuk membuka setiap halaman menjadi layaknya sebuah buku. Jadi dapat disimpulkan bahwa dengan software ini apabila kita membaca sebuah ebook tidak lagi monoton dan menjadi lebih menarik.

Materi yang digunakan dalam penelitian ini adalah segitiga karena menggunakan model discovery learning sangat cocok dan memudahkan siswa untuk belajar menemukan sendiri konsep atau menyelesaikan masalah yang berkaitan dengan materi tersebut. Modul matematika berbasis model discovery learning berbantu media flipbook maker diharapkan dapat memaksimalkan potensi siswa, khususnya pada kemampuan pemahaman konsep.

Berdasarkan latar belakang di atas maka penelitian ini bertujuan untuk (1) mengetahui bagaimana pengembangan modul matematika berbasis Discovery Learning berbantuan Flipbook Maker yang valid untuk meningkatkan kemampuan pemahaman konsep siswa pada materi segitiga dan (2) untuk Mengetahui apakah modul matematika berbasis Discovery Learning berbantuan Flipbook Maker efektif untuk meningkatkan kemampuan pemahaman konsep siswa pada materi segitiga.

\section{METODE PENELITIAN}

Model pengembangan yang digunakan dalam penelitian dan pengembangan ini adalah model ADDIE. Karena model ini dikembangkan secara sistematis dan berpihak pada landasan teoritis desain pembelajaran. Menurut Pribadi, B. A. (2009:127) model ADDIE terdiri dari lima fase atau tahap utama. Kelima fase model pembelajaran ADDIE 
adalah Analysis (Analisis), Design (Perancangan), Development (Pengembangan), Implementation (Implementasi) dan Evaluation (evaluasi).

Sebelum dilakukan penelitian maka produk yang sudah dihasilkan akan validasi oleh ahli. Validasi ahli dilakukan untuk mengetahui kelayakan modul matematika berbasis discovery learning berbantuan flipbook maker. Validasi produk dilakukan dengan cara menghadirkan beberapa pakar atau tenaga ahli yang sudah berpengalaman untuk menilai produk yang baru dirancang. Subjek yang melakukan validasi produk terdiri dari validator materi dan validator media. Penelitian dilakukan di SMP Negeri 1 Mlonggo Jepara pada tanggal 11 Mei 2015 sampai 26 Mei 2015. Subjek pada penelitian ini adalah kelas VII SMP dengan populasi seluruh kelas VII SMP Negeri 1 Mlonggo. Dengan teknik cluster random sampling didapatkan kelas VII D sebagai kelas eksperimen dan kelas VII E sebagai sampel. Untuk kelas ujicoba instrument penelitian adalah kelas VIII C.

Teknik pengumpulan data dalam penelitian ini adalah dengan metode dokumentasi untuk memperoleh data dan mencatat semua peristiwa pada saat penelitian, metode observasi untuk memperoleh gambaran dalam proses penelitian, metode angket untuk mengetahui penilaian terhadap modul matematika yang dilakukan oleh validator materi dan validator media serta siswa kelas eksperimen dalam menanggapi modul matematika sebagai bahan ajar yang diberikan, metode tes untuk mengukur hasil belajar siswa. Sebelum tes diujikan pada kelas eksperimen dan kelas kontrol akan diujicobakan dulu pada kelas ujicoba untuk mengetahui layak atau tidaknya instrument tersebut. Karena penelitian ini untuk mengukur kemampuan pemahaman konsep siswa maka soal didesain berdasarkan indikator kemampuan pemahaman konsep.

Analisis terhadap data validasi ahli dan tanggapan siswa, data kuantitatif skor penilaian diperoleh dari hasil pengisian angket validator materi dan validator media serta siswa dianalisis dengan acuan yang diadaptasi dengan menggunakan skala likert yang nantinya akan dideskripsikan secara kualitatif. Untuk mengetahui kelayakan soal ujicoba dilakukan analisis butir soal dengan menghitung validitas, reliabilitas, taraf kesukaran dan daya pembeda. Analisis awal menggunakan nilai UTS semester 2 yang bertujuan untuk mengetahui keadaan awal sampel. Analisis data awal digunakan uji normalitas sampel (uji lilliefors) dan uji homogenitas sampel (uji bartlett). Data akhir berupa data nilai tes evaluasi dari hasil tes instrument penelitian materi pokok segitiga yang kemudian dianalisis menggunakan uji normalitas sampel (uji lilliefors), uji homogenitas sampel, dan 
uji t pihak kanan. Serta analisis jawaban untuk mengetahui peningkatan kemampuan pemahaman konsep siswa

\section{HASIL DAN PEMBAHASAN}

Validator materi yang memvalidasi produk adalah Sugiyanti, M.Pd., Istifaiyah, S.Pd. dan Suraningsih Apriliastuti, S.Pd. Hasil dari penilaian aspek ahli materi menempatkan pada beberapa kriteria. Pada aspek umum (80,56\%), aspek discovery learning $(80,56 \%)$, aspek kemampuan pemahaman konsep $(78,57 \%)$ mempunyai kriteria baik karena berada pada rentang 61\%-81\% sedangkan aspek substansi materi $(81,25 \%)$ dan aspek desain pembelajaran $(85,42 \%)$ mempunyai kriteria sangat baik karena berada pada rentang 81\%-100\%. Secara keseluruhan persentase kelayakan dari tiga validator adalah $82,03 \%$ yang berada pada kategori sangat baik. Validator media yang memvalidasi produk adalah Febrian MD., M.Kom, Dina Prasetyowti, S.Pd., M.Pd. dan Arif Z Fuadi, S.Kom. Hasil dari penilaian aspek ahli media menempatkan pada beberapa kriteria. Pada aspek kelayakan bahasa $(80,56 \%)$, aspek discovery learning $(80,56 \%)$ mempunyai kriteria baik karena berada pada rentang 61\%-81\% sedangkan aspek umum (81,25\%), Aspek penyajian pembelajaran (85\%) dan aspek kelayakan kegrafikan $(81,94 \%)$ mempunyai kriteria sangat baik karena berada pada rentang 81\%-100\%. Secara keseluruhan persentase kelayakan dari tiga validator adalah $81,25 \%$ yang berada pada kategori sangat baik.

Hasil tanggapan siswa terhadap modul matematika menempatkan posisi pada kriteria sangat baik karena aspek umum $(83,71 \%)$, aspek materi $(82,35 \%)$, dan aspek rekayasa bahasa $(86,51 \%)$ berada pada rentan $81 \%-100 \%$. Secara keseluruhan persentase tanggapan siswa adalah $83,92 \%$ berada pada kategori sangat baik. Pada tahap ujicoba soal dari 12 soal uraian yang diujicobakan hanya 8 soal yang layak sebagai instrument penelitian yang akan diujikan pada kelas eksperimen dan kelas kontrol yaitu butir soal nomor $1,3,4,5,6,8,9,12$. Hal ini dikarenakan ada 8 soal yang valid, mempunyai reliabilitas tinggi, mempunyai tingkat kesukaran yang dapat mengukur aspek yang terurai dalam standar kompetensi dan memiliki 8 soal yang daya pembedanya signifikan.

Analisis data awal menggunakan data nilai UTS semeseter 2. Pada perhitungan normalitas didapat $\mathrm{L}_{\text {hitung }}=0,097$ dengan $\mathrm{n}=38$ dan $\alpha=0,05$ didapat $\mathrm{L}_{\text {tabel }}=0,144$ untuk kelas eksperimen sedangkan untuk kelas kontrol $\mathrm{L}_{\mathrm{hitung}}=0,094$ dengan $\alpha=0,05$ dan dan $\mathrm{n}$ $=38$ didapat $\mathrm{L}_{\text {tabel }}=0,144$ karena $\mathrm{L}_{\text {hitung }}{ }^{<} \mathrm{L}_{\text {tabel }}$ maka $\mathrm{H}_{0}$ diterima jadi sampel berasal dari distribusi normal. Uji homogenitas digunakan untuk menguji kesamaan dua varians. Dari 
perhitungan data awal diperoleh $\chi_{o b s}^{2}={ }^{0,0124}$ Dengan $\alpha=5 \%$ dan $\mathrm{dk}(2-1)=3,841$. DK $=\left\{\chi^{2} \mid \chi_{\text {obs }}^{2}>\quad 3,841\right\}$ sehingga $\chi_{\text {obs }}^{2}=0,0124 \notin$ DK. Jadi $\chi_{o b s}^{2}=0.0124<\chi_{\text {tabel }\left(\alpha_{j} 1\right)}^{2}=3,841$ maka $\mathrm{H}_{0}$ diterima, sehingga dapat disimpulkan varians antar kelompok homogen (sama).

Untuk analisi data akhir menggunakan tes pada instrument penelitian Uji normalitas didapat $\mathrm{L}_{\text {hitung }}=0,061$ dengan $\mathrm{n}=38$ dan $\alpha=0,05$ didapat $\mathrm{L}_{\text {tabel }}=0,144$ untuk kelas eksperimen sedangkan untuk kelas kontrol $\mathrm{L}_{\text {hitung }}=0,090$, dan $\alpha=0,05$ dan dan $\mathrm{n}=38$ didapat $\mathrm{L}_{\text {tabel }}=0,144$ karena $\mathrm{L}_{\text {hitung }}<\mathrm{L}_{\text {tabel }}$ maka $\mathrm{H}_{0}$ diterima jadi sampel berasal dari distribusi normal. Uji homogenitas digunakan untuk menguji kesamaan dua varians. Dari perhitungan data akhir diperoleh $\chi_{o b s}^{2}=0,002$ Dengan $\alpha=5 \%$ dan $\operatorname{dk}(2-1)=3,841$. DK $=\left\{\chi^{2} \mid \chi_{\text {obs }}^{2}>\quad 3,841\right\} \quad$ sehingga $\quad \chi_{\text {obs }}^{2}=0,002 \notin \quad$ DK. Jadi $\chi_{o b s}^{2}=0.002<\chi_{\text {tabel( } \alpha ; 1)}^{2}=3,841$ maka $\mathrm{H}_{0}$ diterima, sehingga dapat disimpulkan varians antar kelompok homogen (sama).

Uji hipotesis yang akan digunakan adalah uji hipotesis uji-t pihak kanan dengan $\mathrm{H}_{0}$ : $\mu_{1}=\mu_{2}$ (Rata-rata hasil belajar siswa yang menggunakan modul matematika berbasis discovery learning berbatuan flipbook maker pada materi segitiga sama dengan rata-rata hasil belajar siswa yang tidak menggunakan modul matematika berbasis discovery learning berbatu flipbook maker pada materi segitiga) dan H1 : $\mu_{1}>\mu_{2}$ (Rata-rata hasil belajar siswa yang menggunakan modul matematika berbasis discovery learning berbatuan flipbook maker pada materi segitiga lebih baik dari pada rata-rata hasil belajar siswa yang tidak menggunakan modul matematika berbasis discovery learning berbatuan flipbook maker pada materi segitiga). Sehingga perhitungannya diperoleh $\overline{X_{1}}=78,184$ dan $\overline{X_{2}}=70,053, \mathrm{n} 1=38, \mathrm{n} 2=38$ dan $\mathrm{s}_{\text {total }}=11,621$ sehingga diperoleh $\mathrm{t}_{\text {hitung }}=3,050$. Hasil

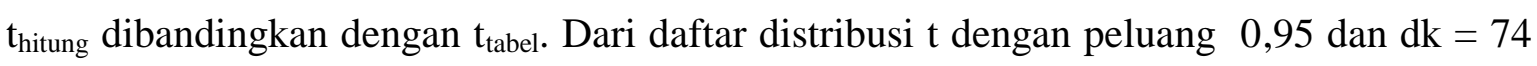
maka t $0,95(74)$ adalah 1,67. $D K=\{t l t>1,67\}$ dan $t=3,050 \in D K$. Karena $L_{\text {hitung }}>L_{\text {tabel }}$ maka $\mathrm{H}_{0}$ ditolak, sehingga dapat disimpulkan rata-rata hasil belajar siswa yang menggunakan modul matematika berbasis discovery learning berbatuan flipbook maker pada materi segitiga lebih baik dari pada rata-rata hasil belajar siswa yang tidak 
menggunakan modul matematika berbasis discovery learning berbantuan flipbook maker pada materi segitiga.

Berikut merupakan analisis jawaban siswa delapan soal instrument penelitian yang diberikan pada kelas eksperimen dan kelas kontrol didapatkan tiga tipe jawaban siswa, yaitu jawaban benar dan lengkap, jawaban benar tapi tidak lengkap dan jawaban salah atau tidak dijawab. Berikut ini merupakan tebel persentase jumlah siswa pada tiga tipe jawaban.

Tabel 1. Persentase Jawaban Siswa Kelas Eksperimen

\begin{tabular}{cccc}
\hline No & $\begin{array}{c}\text { Jawaban Benar } \\
\text { dan Lengkap }\end{array}$ & $\begin{array}{c}\text { Jawaban Benar tapi Tidak } \\
\text { Lengkap }\end{array}$ & $\begin{array}{c}\text { Jawaban Salah atau } \\
\text { Tidak Dijawab }\end{array}$ \\
\hline $\mathbf{1}$ & $89.47 \%$ & $10.53 \%$ & $0 \%$ \\
$\mathbf{2}$ & $78.95 \%$ & $21.05 \%$ & $0 \%$ \\
$\mathbf{3}$ & $92.11 \%$ & $7.89 \%$ & $0 \%$ \\
$\mathbf{4}$ & $34.21 \%$ & $65.79 \%$ & $0 \%$ \\
$\mathbf{5}$ & $60.53 \%$ & $39.47 \%$ & $0 \%$ \\
$\mathbf{6}$ & $86.84 \%$ & $13.16 \%$ & $0 \%$ \\
$\mathbf{7}$ & $15.79 \%$ & $81.58 \%$ & $2.63 \%$ \\
$\mathbf{8}$ & $34.21 \%$ & $65.79 \%$ & $0 \%$ \\
Jumlah & $492.11 \%$ & $305.26 \%$ & $2.63 \%$ \\
Rata-Rata & $61.51 \%$ & $38.16 \%$ & $0.33 \%$ \\
\hline
\end{tabular}

Tabel 2. Persentase Jawaban Siswa Kelas Kelas Kontrol

\begin{tabular}{cccc}
\hline No & $\begin{array}{c}\text { Jawaban Benar } \\
\text { dan Lengkap }\end{array}$ & $\begin{array}{c}\text { Jawaban Benar tapi } \\
\text { Tidak Lengkap }\end{array}$ & $\begin{array}{c}\text { Jawaban Salah atau Tidak } \\
\text { Dijawab }\end{array}$ \\
\hline $\mathbf{1}$ & $78.94 \%$ & $18.42 \%$ & $0 \%$ \\
$\mathbf{2}$ & $84.21 \%$ & $15.79 \%$ & $0 \%$ \\
$\mathbf{3}$ & $18.42 \%$ & $81.58 \%$ & $0 \%$ \\
$\mathbf{4}$ & $76.32 \%$ & $15.79 \%$ & $7.89 \%$ \\
$\mathbf{5}$ & $92.11 \%$ & $7.89 \%$ & $0 \%$ \\
$\mathbf{6}$ & $52.63 \%$ & $42.11 \%$ & $5.26 \%$ \\
$\mathbf{7}$ & $13.16 \%$ & $68.42 \%$ & $18.42 \%$ \\
$\mathbf{8}$ & $7.89 \%$ & $78.95 \%$ & $13.16 \%$ \\
Jumlah & $344.74 \%$ & $328.95 \%$ & $44.73 \%$ \\
Rata-Rata & $49.25 \%$ & $41.12 \%$ & $5.59 \%$ \\
\hline
\end{tabular}

Dari tabel 1 dan tabel 2 terlihat bahwa untuk kelas eksperimen pada tipe jawaban benar dan lengkap mempunyai rata-rata paling tinggi yaitu 61,51\%. Kelas kontrol mempunyai rata-rata $49,25 \%$. Siswa yang menjawab pada tipe jawaban benar tapi tidak lengkap mempunyai rata-rata $38,16 \%$ pada kelas eksperimen dan $41,12 \%$ pada kelas kontrol. Siswa yang menjawab salah atau tidak menjawab rata-ratanya paling sedikit yaitu 0,33\% pada kelas eksperimen dan $5.59 \%$ pada kelas kontrol. Sehingga siswa yang 
menjawab soal dengan benar dan lengkap lebih banyak pada kelas eksperimen dibandingkan dengan kelas kontrol. Sedangkan untuk siswa yang menjawab soal dengan benar tapi tidak lengkap serta menjawab salah atau tidak dijawab lebih banyak dari kelas kontrol dari pada kelas eksperimen.

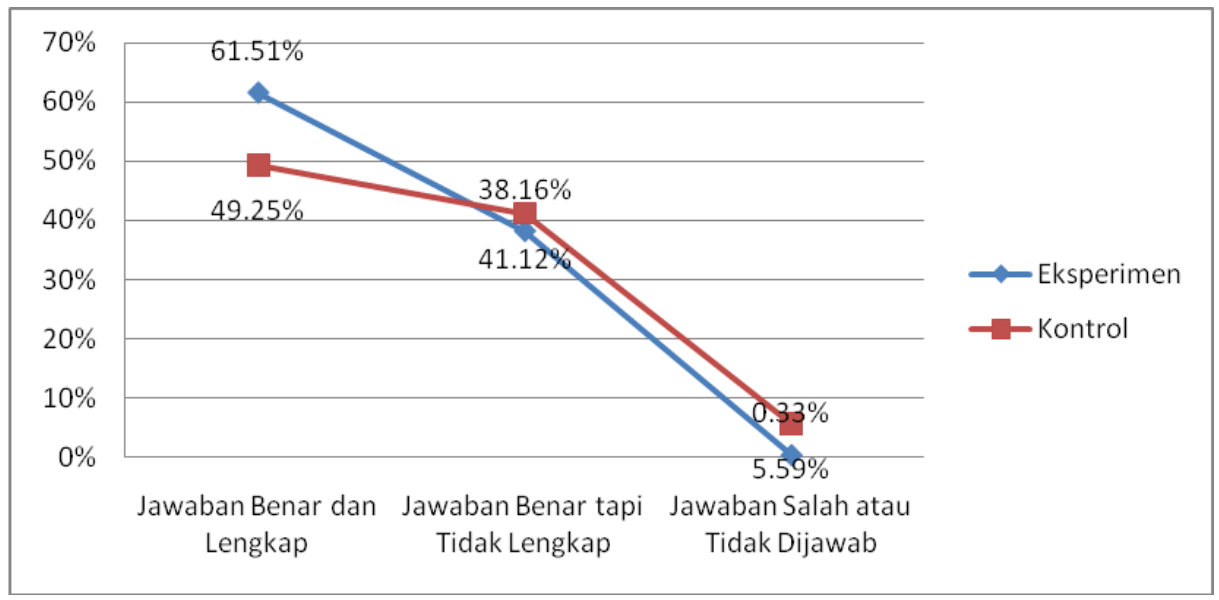

Gambar 1. Grafik Jumlah siswa dengan Tiga Tipe Jawaban

Dari gambar 1, grafik tersebut terlihat jelas bahwa terjadi peningkatan siswa yang menjawab soal dengan benar dan lengkap namun terjadi penurunan siswa yang menjawab soal dengan benar tapi tidak lengkap dan menjawab salah atau tidak dijawab. Untuk siswa yang menjawab benar dan lengkap mempunyai selisih paling besar. Namun siswa yang menjawab benar tapi tidak lengkap dan salah atau tidak dijawab mempunyai selisih yang sedikit.

Indikator kemampuan pemahaman konsep ada tujuh. Untuk soal nomor 1 mencakup indikator pertama, soal nomor 2 mencakup indikator pertama dan kedua, soal nomor 3 mencakup indikator kedua,keempat dan keenam, soal nomor 4 dan 5 mencakup indikator kelima dan keenam, soal nomor 6 mencakup indikator keempat, keenam dan ketujuh, soal nomor 7 mencakup indikator kelima, keenam dan ketujuh, soal nomor 8 mencakup indikator ketiga dan kelima. Untuk mengetahui seberapa banyak siswa yang mencapai indikator kemampuan pemahaman konsep, maka berikut ini merupakan tabel persentase ketercapaian indikator kemampuan pemahaman konsep siswa. 
Tabel 3. Persentase Ketercapaian Indikator Kemampuan Pemahaman Konsep Kelas Eksperimen

\begin{tabular}{cccccccc}
\hline No Soal & \multicolumn{7}{c}{ Ketercapaian Indikator Kemampuan Pemahaman Konsep } \\
& 1 & 2 & 3 & 4 & 5 & 6 & 7 \\
\hline $\mathbf{t i m}$ & $89.47 \%$ & - & - & - & - & - & - \\
$\mathbf{2}$ & $78.95 \%$ & $100 \%$ & - & - & - & & - \\
$\mathbf{3}$ & - & $100 \%$ & - & $92.11 \%$ & - & $100 \%$ & - \\
$\mathbf{4}$ & - & - & - & - & $76.32 \%$ & $57.89 \%$ & - \\
$\mathbf{5}$ & - & - & - & - & $94.74 \%$ & $65.79 \%$ & - \\
$\mathbf{6}$ & - & - & - & $100 \%$ & & $97.37 \%$ & $86.84 \%$ \\
$\mathbf{7}$ & - & - & - & - & $21.05 \%$ & $63.16 \%$ & $73.68 \%$ \\
$\mathbf{8}$ & - & - & $71.05 \%$ & - & $63.16 \%$ & - & - \\
Rata-Rata & $84.21 \%$ & $100.00 \%$ & $71.05 \%$ & $96.06 \%$ & $63.82 \%$ & $76.84 \%$ & $80.26 \%$ \\
\hline
\end{tabular}

Dengan melihat tabel 3 dapat diperoleh beberapa kesimpulan yaitu (a) Dapat dilihat dari rata-ratanya siswa yang mencapai indikator kelima mempunyai persentase paling rendah yaitu 63,82\%. Sedangkan siswa yang mencapai indikator kedua mencapai $100 \%$. Secara keseluruhan rata-rata siswa kelas eksperimen yang mencapai setiap indikator terbilang tinggi. Karena jumlah siswa pada masing-masing indikator mencapai 50\% lebih yang artinya setengah dari jumlah siswa. (b) Melihat kecenderungan data, kelas eksperimen mempunyai kurva yang naik turun dari indikator pertama sampai keempat sedangkan pada indikator kelima sampai kedelapan kurva akan naik.

Tabel 4. Persentase Ketercapaian Indikator Kemampuan Pemahaman Konsep Kelas Kontrol

\begin{tabular}{cccccccc}
\hline No Soal & \multicolumn{7}{c}{ Ketercapaian Indikator Kemampuan Pemahaman Konsep } \\
& 1 & 2 & 3 & 4 & 5 & 6 & 7 \\
\hline $\mathbf{1}$ & $78.94 \%$ & - & - & - & - & - & - \\
$\mathbf{2}$ & $84.21 \%$ & $100 \%$ & - & - & - & & - \\
$\mathbf{3}$ & - & $31.59 \%$ & - & $76.32 \%$ & - & $60.53 \%$ & - \\
$\mathbf{4}$ & - & - & - & - & $89.47 \%$ & $78.95 \%$ & - \\
$\mathbf{5}$ & - & - & - & - & $100 \%$ & $92.11 \%$ & - \\
$\mathbf{6}$ & - & - & - & $84.47 \%$ & - & $78.94 \%$ & $52.63 \%$ \\
$\mathbf{7}$ & - & - & - & - & $23.68 \%$ & $55.26 \%$ & $44.74 \%$ \\
$\mathbf{8}$ & - & - & $63.16 \%$ & - & $31.58 \%$ & - & - \\
Rata-Rata & $81.58 \%$ & $65.80 \%$ & $63.16 \%$ & $80.40 \%$ & $61.18 \%$ & $73.16 \%$ & $48.69 \%$ \\
\hline
\end{tabular}

Dengan melihat tabel 4 dapat diperoleh beberapa kesimpulan yaitu a) rata-rata siswa kelas kontrol yang paling tingg pada indikator pertama dan rata-rata siswa yang paling rendah pada indikator ketujuh. b) Melihat kecenderungan data, kelas kontrol mempunyai kurva menurun dari indikator pertama sampai ketiga dan akan naik turun dari 
indikator keempat sampai ketujuh. Berikut ini merupakan grafik persentase ketercapaian indikator kemampuan pemahaman konsep.

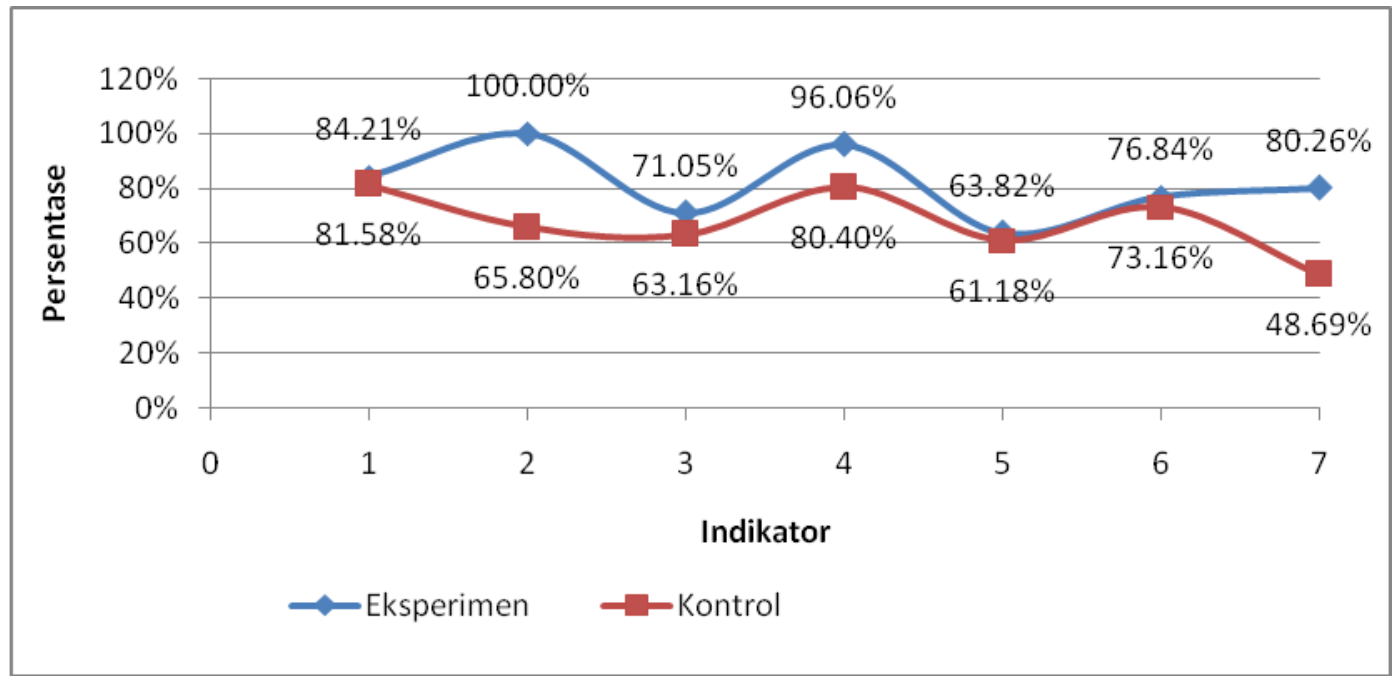

Gambar 2. Grafik Ketercapaian Indikator Kemampuan Pemahaman Konsep Siswa Kelas Eksperimen dan Kelas Kontrol

Dengan melihat grafik 2 diperoleh beberapa kesimpulan dalam penelitian ini, yaitu a) terjadi peningkatan jumlah siswa yang mencapai seluruh indikator kemampuan pemahaman konsep b) Pada Kelas Eksperimen, dari indikator pertama sampai indikator kelima mempunyai kurva yang naik turun kemudian akan naik sampai indikator ketujuh. Sedangkan pada kelas kontrol kurvanya menurun dari indikator pertama sampai ketiga dan selajutnya akan naik turun. Peningkatan paling tinggi terlihat pada indikator kedua dan peningkatan paling rendah pada indikator kelima.

Berikut ini merupakan beberapa contoh jawaban siswa.

a) Soal nomor 1

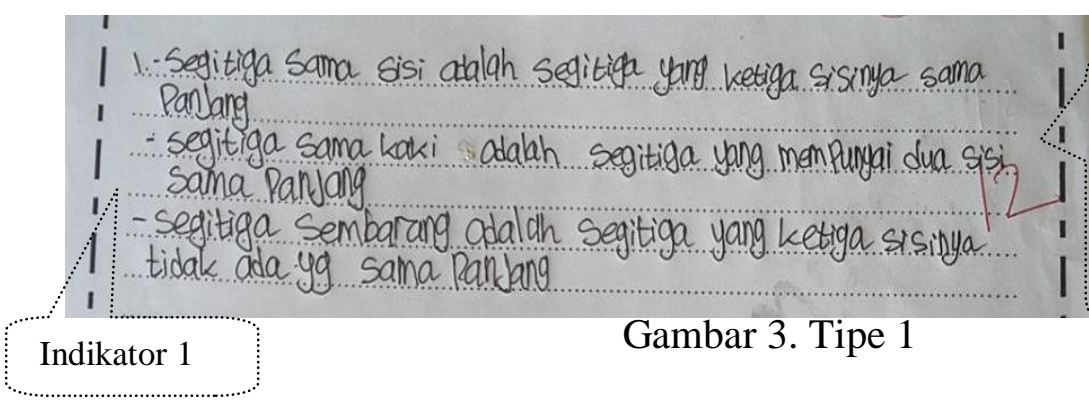

Menyebutkan tiga jenis segitiga berdasarkan panjang sisi dan pengertianya secara benar dan lengkap

Dari gambar 3 terlihat bahwa indikator 1 siswa menjawab dengan benar dan lengkap sehingga jawaban tersebut mendapat skor secara sempurna. Pada kelas eksperimen ada 34 siswa menjawab secara lengkap dan 4 siswa yang jawabanya belum lengkap. Sedangkan untuk kelas kontrol semua siswa menjawab benar dan lengkap. Sehingga siswa dapat menyatakan ulang sebuah konsep. 
b) Soal nomor 2

Indikator 2

Gambar 4. Tipe 1

Dari gambar 4 terlihat bahwa indikator 1 terpenuhi. Semua siswa dari kelas eksperimen dan kelas kontrol dapat menjawab soal nomor 2 dengan indikator 2. Namun pada indikator 1 masih ada siswa yang menjawab kurang lengkap.

c) Soal nomor 3

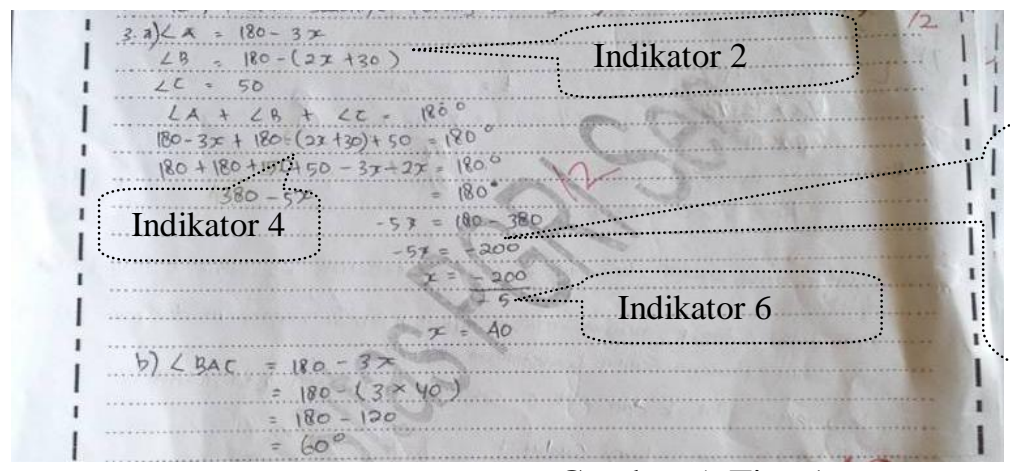

Siswa mengelompokkan masing-masing sudut . dan mengolah persamaan yang sudah jadi dengan jelas dan runtut

Gambar 5. Tipe 1

Dari gambar 5 soal nomor 3 tersebut dijawab dengan benar dan lengkap. Ada 35 siswa kelas eksperimen dan 7 siswa kelas kontrol yang menjawab dengan benar dan lengkap.

d) Soal nomor 4

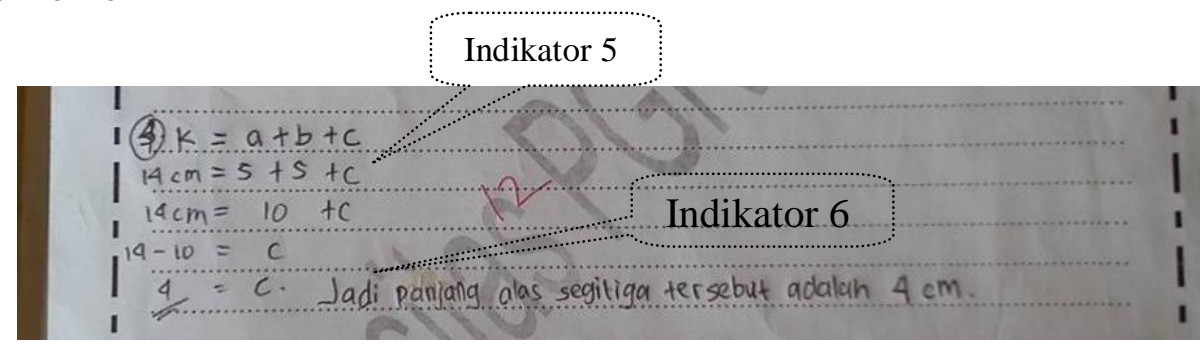

Gambar 6. Tipe 1

Pada gambar 6 sudah terlihat bahwa soal tersebut dijawab dengan benar dan lengkap. Ada 13 siswa kelas eksperimen dan 29 siswa kelas kontrol yang menjawab benar dan lengkap sehingga siswa sudah dapat mengembangkan syarat perlu dan syarat cukup suatu konsep serta menggunakan, memanfaatkan dan memilih prosedur atau operasi tertentu. 


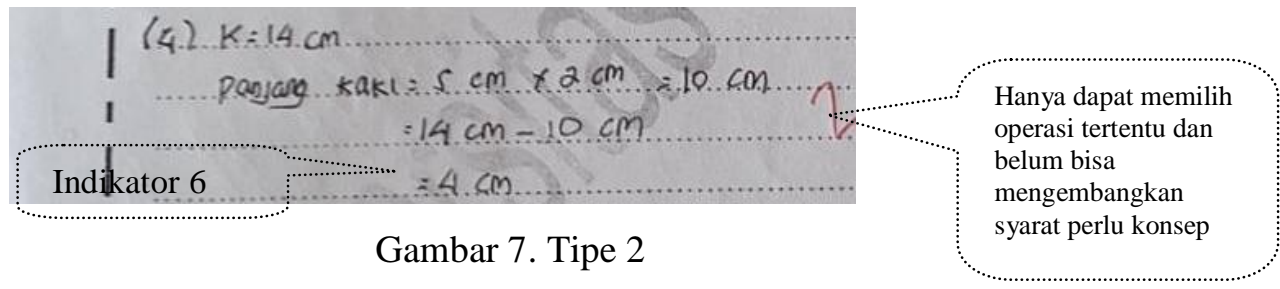

Pada gambar 7 jawaban tersebut kurang lengkap dan hanya benar pada hasilnya. Untuk jawaban tipe 2 ada 25 siswa kelas eksperimen dan 6 siswa kelas kontrol.

e) Soal nomor 5

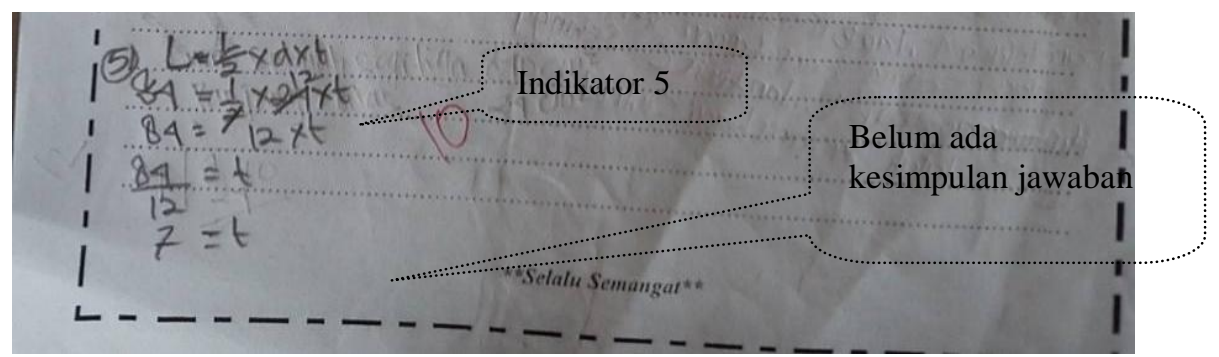

Gambar 8. Tipe 2

Pada gambar 8 jawaban kurang lengkap. Yang menjawab soal no 5 dengan tipe 5 ada 18 siswa.

f) Soal nomor 6

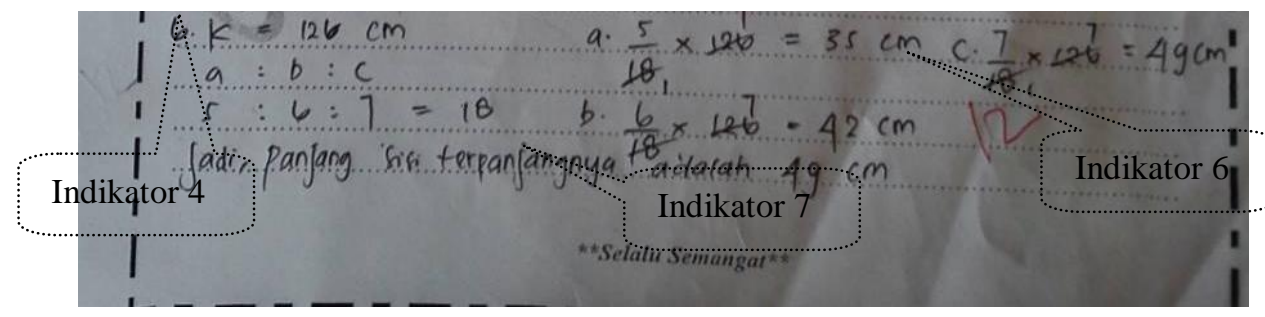

Gambar 9. Tipe 1

Dari gambar 9 terlihat jelas jawaban siswa secara lengkap dan benar pada hasil akhir. Ada 53 siswa dari kelas eksperimen dan kelas kontrol yang menjawab soal nomor 6 secara benar dan lengkap sehingga indikator 4, 6 dan 7 dapat terpenuhi.

g) Soal nomor 7

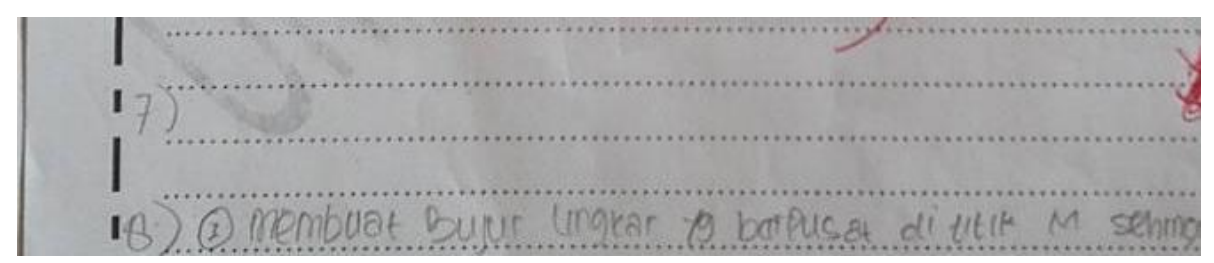

Gambar 10. Tipe 3

Dari gambar 10 merupakan contoh jawaban tipe 3. Ada 8 siswa yang mempunyai jawaban dengan tipe 3 . 
h) Soal nomor 8

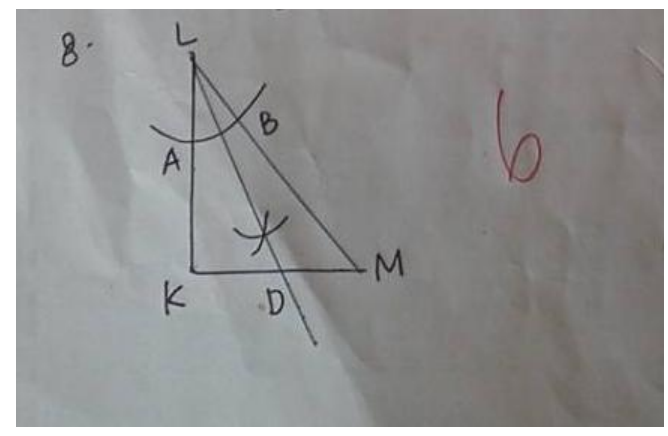

Gambar 11. Tipe 2

Dari gambar 11 terlihat jawaban kurang lengkap karena belum ada langkah-langkah dalam melukis. Ada 55 siswa dari kelas eksperimen dan kelas kontrol yang menjawab soal nomor 8 dengan jawaban yang kurang lengkap.

Dari hasil analisis jawaban siswa, terjadi peningkatan jumlah siswa yang menjawab soal dengan benar dan lengkap antara kelas kontrol dan kelas eksperimen. Namun terjadi penurunan siswa yang menjawab soal dengan benar tapi tidak lengkap dan siswa yang menjawab salah atau tidak menjawab. Hal ini menunjukkan hasil belajar siswa kelas eksperimen lebih baik dari pada kelas kontrol karena siswa yang menjawab benar lebih banyak pada kelas eksperimen sedangkan yang menjawab salah lebih banyak pada kelas kontrol. Ini juga dibuktikan dengan ketercapaian jumlah siswa yang mencapai indikator kemampuan pemahaman konsep. Dari indikator pertama sampai indikator ketujuh terjadi peningkatan antara siswa kelas kontrol dan kelas eksperimen. Peningkatan paling rendah ada pada indikator kelima yaitu mengembangkan syarat perlu dan syarat cukup suatu konsep, yang berarti tidak ada perbedaan yang signifikan kemampuan siswa pada kedua kelas dalam mengembangkan syarat perlu dan syarat cukup suatu konsep. Sedangkan peningkatan paling tinggi terjadi pada indikator kedua. Dalam hal ini ada perbedaan kemampuan dari kedua kelas untuk mengklasifikasikan obyek-obyek menurut sifat-sifat tertentu.

Dari pembahasan terhadap data hasil penelitian maka dapat disimpulkan penggunaan modul matematika yang dikembangkan lebih baik dibandingkan dengan model konvensional pada proses pembelajaran. Rata-rata nilai yang dihasilkan kelas ekseprimen lebih baik dibandingkan kelas kontrol, hal itu disebabkan pada saat terjadinya proses belajar mengajar, siswa kelas eksperimen lebih antusias dalam mengikuti pembelajaran dan mengerjakan soal-soal latihan yang ada. Dapat dilihat dari hasil 
observasi aktifitas siswa kelas eksperimen yang rata-rata siswa mempunyai aktifitas yang baik.

Sehingga dapat juga disimpulkan bahwa kelas eksperimen yang menggunakan modul matematika dapat dikatakan efektif untuk meningkatkan kemampuan pemahaman konsep siswa pada materi segitiga. Hal ini sesuai dengan hipotesis penelitian yaitu $\mathrm{H}_{1}$ diterima maka modul matematika berbasis discovery learning berbantuan flipbook maker efektif untuk meningkatkan kemampuan pemahaman konsep siswa pada materi segitiga.

\section{KESIMPULAN}

Berdasarkan rumusan masalah, pengajuan hipotesis, analisis data penelitian dan pembahasan masalah maka dapat disimpulkan sebagai berikut :

1. Pengembangan modul matematika berbasis discovery learning berbantuan flipbook maker untuk meningkatkan kemampuan pemahaman konsep siswa pada materi segitiga layak digunakan oleh siswa dengan melihat penilaian dari tiga ahli materi $82,03 \%$ menyatakan layak digunakan. Sedangkan tiga ahli media $81,25 \%$ menyatakan layak digunakan dalam proses pembelajaran. Hasil dari tanggapan siswa terhadap modul matematika berbasis discovery learning berbantuan flipbook maker didapatkan persentase kelayakan sebesar $83,92 \%$. Setelah dikonversikan dengan tabel konversi skala maka tingkat pencapaian $83,92 \%$ berada pada kategori sangat baik. Jadi modul matematika berbasis discovery learning berbantuan flipbook maker valid digunakan untuk meningkatkan kemampuan pemahaman konsep siswa pada materi segitiga.

2. Rata-rata hasil belajar siswa yang menggunakan modul matematika berbasis discovery learning berbatuan flipbook maker pada materi segitiga lebih baik dari pada rata-rata hasil belajar siswa yang tidak menggunakan modul matematika berbasis discovery learning berbantuan flipbook maker pada materi segitiga. Hal ini dibuktikan dari hasil uji t yang diperoleh, dalam analisisnya dapat disimpulkan bahwa $H_{o}$ ditolak. Sehingga modul matematika berbasis discovery learning berbantuan flipbook maker efektif untuk meningkatkan kemampuan pemahaman konsep siswa pada materi segitiga.

\section{REFERENSI}

Dahar, R. W. (1996). Teori-Teori Belajar. Bandung: Erlangga 
Herawati, O. D. P., Siroj, R. A., \& Basir, M. D. (2010). Pengaruh pembelajaran problem posing terhadap kemampuan pemahaman konsep matematika siswa kelas xi ipa sma negeri 6 palembang. Jurnal Pendidikan Matematika, 4(1), 70-80.

Misdalina, M., Zulkardi, Z., \& Purwoko, P. (2009). Pengembangan Materi Integral untuk Sekolah Menengah Atas (SMA) Menggunakan Pendekatan Pendidikan Matematika Realistik Indonesia (PMRI) di Palembang. Jurnal Pendidikan Matematika, 3(1), 61-74.

Pribadi, B. A. (2009). Model Desain Sistem Pembelajaran. Jakarta: Dian Rakyat

Rahmawati, D. D. (2014). Pengembangan Modul Matematika Berbasis Group Investigation (GI) Berbantu Flipbook maker pada kelas X Pokok Bahasan Matriks. Skripsi Sarjana Program Studi Pendidikan Matematika Fakultas Pendidikan Matematika dan Ilmu Pengetahuan Alam. Semarang: Universitas PGRI Semarang.

Rizkafiati, M. (2014). Pengembangan Modul Pembelajaran dengan Model Discovery Learning Berbasis Kurikulum 2013 Berbantuan Macromedia Flash pada materi Segiempat. Skripsi Sarjana Program Studi Pendidikan Matematika Fakultas Pendidikan Matematika dan Ilmu Pengetahuan Alam. Semarang Semarang:Universitas PGRI Semarang

Suherman, E., dkk. (2003). Strategi Pebelajaran Matematika Kontemporer. Bandung: JICA

Wardhani, S. (2008). Analisis SI dan SKL Mata Pelajaran Matematika SMP/MTs untuk Optimalisasi Tujuan Mata Pelajaran Matematika.Yogyakarta: PPPPTK.

Wena, M. 2013. Strategi Pembelajaran Inovatif Kontemporer. Jakarta: Bumi aksara

Yenni, \& Komalasari, R. (2016). Pengaruh Model Pembelajaran Learning Cycle Terhadap Kemampuan Pemahaman dan Koneksi Matematis Siswa SMP. KALAMATIKA, 1(1), 71-83. 